\title{
Foucault, Derrida e a História da Loucura: notas sobre uma polêmica
}

\author{
Foucault, Derrida, and the history of madness: \\ notes on a controversy
}

André de Faria Pereira Neto 1

1 Casa de Oswaldo Cruz, Fundação Oswaldo Cruz. Av. Brasil 4036, sala 401, Rio de Janeiro, RJ 21040-361, Brasil. apereira@sitelocal.com
Abstract The publication of the book Folie et Déraison. Histoire de la Folie à l'âge Classique (1961), by Michel Foucault, sparked a debate between the author and philosopher Jacques Derrida during the 1960s and 70s. Derrida criticized the methodological proposal and organization of the History of Madness presented by Foucault in the foreword to the first edition. The controversy appears to have moti vated the author to withdraw this same foreword from the second edition. The purpose of this article is to analyze some current points in this controversy. It al so presents a research agenda for an understanding of the reasons leading Foucault to take this stance. Key words Mental Health; Philosophy; History of Science

Resumo A publicação do livro Folie et Déraison. Histoire de la Folie à l'âge Classique (1961), de Michel Foucault, promoveu um debate entre o autor eo filósofo Jacques Derrida, durante os anos 60/70. Derrida criticou a proposta metodológi ca ea organização da História da Loucura, apresentadas por Foucault, no prefácio da primeira edição. Essa polêmica pareceter motivado o autor a retirar, da segunda edição, o prefáci o que abria a primei ra versão do livro. O obj etivo deste artigo é analisar al guns pontos presentes nesta controvérsia. Além disso, ele apresenta uma agenda de pesqui sa para o entendimento das razões que levaram Foucault a tomar tal atitude. Palavras-chave Saúde Mental; Filosofia; História da Ciência 


\section{Introdução}

Em 1961, Michel Foucault publicou em Paris Folie et Déraison. Histoire de la Folie à l'âge Classique, um livro que se tornou obra de referência na área da filosofia, história, psicologia, saúde mental e coletiva. Em 1963, no Colégio Filosófico, Jacques Derrida proferiu uma conferência em que criticava esta obra de Foucault, particularmente seu prefácio. Com a publicação de sua segunda edição francesa (1972), Foucault retira o prefácio da primeira versão e responde, em um apêndice, às críticas feitas por Derrida. A partir do final da década de 70 , - livro passou a ser traduzido para diversos idiomas, e todas estas edições saíram amputadas. Faltava-Ihes o prefácio.

No nosso entender, a periodização adotada e a metodologia proposta por Foucault para a el aboração de uma história da loucura foram as duas questões, presentes no prefácio, que polarizaram as críticas de Derrida. Houve ainda uma polêmica entre os dois pensadores contemporâneos sobre a interpretação que Foucault deu às Meditações, de Descartes. Como esta controvérsia não pertence ao prefácio, preferimos acompanhar, neste artigo, a discussão sobre a periodização e a metodologia adotadas por Foucault na História da Loucura. Por fim, propomos uma agenda de pesquisa sobre este interessante episódio da história das idéias contemporâneas.

\section{A periodização da História da Loucura}

\section{A visão de Foucault}

No prefácio da primeira edição, Foucault defende a idéia de que a maneira de o homem lidar com a loucura modificou-se significativamente no século XVIII. Ele afirma:

"A constituição da loucura como doença mental, no fim do século XVIII, atesta um diálogo rompido, dá 'a separação como fato consumado', (destaque nosso) e enterra no esquecimento todas estas palavras imperfeitas, sem sintaxe fixa, um pouco bal buciantes, na qual se dava a troca da loucura eda razão. A linguagem da psiquiatria, queéo monólogo da razão sobre a loucura, só se pode estabelecer sobre tal silêncio" (Foucault, 1961:IV).

Ele justifica esta afirmativa recuperando a maneira pela qual o homem se relacionava com a loucura desde a Antigüidade Clássica, até meados do século XVIII.

"Os gregos relacionam-se com al guma coisa que chamam hybris. Esta rel ação não era so- mente de condenação; (...) mesmo se seu discurso nos é transmitido já 'envol to na dialética tranqüilizadora de Sócrates' (destaque nosso). Mas o logos grego não tinha contrário" (Foucault, 1961:IV).

Até o final do século XVII, segundo Foucault, loucura e razão não estavam ainda separadas. Não havia um vazio entre elas. Loucura e não-loucura, razão e 'des-razão' estariam confusamente implicadas. Para Foucault, durante a Época Moderna, o renascimento científico, associado à filantropia, buscou progressivamente cercar a loucura. Essa tendência se deu dentro da ordem absolutista. Assim ocorreu a passagem da experiência medieval da loucura para a atual, que a confina com o estatuto de doença mental.

Para Foucault, no século XVIII ocorre a experiência-limite entre a razão e a 'des-razão'. Desde então, o homem contemporâneo deixou de se comunicar com o louco. Com o estabelecimento desta divisão originária, a ciência transformou a loucura em um acidente patológico. O homem da loucura passou a ser visto e compreendido através de uma razão igualmente abstrata.

\section{A opinião de Derrida}

Em sua conferência, Derrida admite, igualmente, que houve, no final do século XVIII, uma mudança de postura do homem com relação à loucura.

"A Decisão liga esepara, deuma só vez, razão eloucura; deve ser entendida ao mesmo tempo, aqui, como o ato origi nário de uma ordem, de um 'fiat', de um decreto, e como um 'di laceramento', uma cesura, uma separação, uma discessão. Diria antes 'uma dissensão', para marcar bem que se trata de uma divisão de si, de uma partilha e de um tormento interior do sentido em geral, do 'logos' em geral, de uma partil ha no ato mesmo do 'sentire'" (Derrida, 1967:61).

Discession, no original em francês, refere-se ao prefixo de origem latina dis, que indica separação, diferença, ausência, e cession, que significa transferência de direito de uma para o outro. Assim, para Derrida, o século XVIII não teria inaugurado nada. No seu entender, teria ocorrido tão-somente uma modificação interna e não uma ruptura externa.

Assim, Derrida discorda de Foucault quanto ao caráter da mudança ocorrida na história da loucura, no século XVIII. Derrida entende que Foucault deixou na penumbra uma análise mais criteriosa dos momentos anteriores.

A crítica de Derrida à periodização proposta concentra-se, por outro lado, na maneira 
com que Foucault analisou a loucura na Grécia antiga. Para Derrida, a antigüidade não guardaria, a este respeito, nem especificidade, nem privilégio, tampouco a dialética socrática seria, neste sentido, tranqüilizadora, como afirmou Foucault. Para Derrida, o corte, o momento de mudança de postura do homem em relação à loucura é anterior à antigüidade greco-romana. Situa-se, portanto, há milhares de anos antes de meados do século XVIII.

\section{Postura metodológica}

\section{A visão de Foucault}

Como acabamos de ver, a constituição da loucura como doença mental, no fim do século XVIII, atesta, para Foucault, um diálogo rompido. Metodologicamente falando, Foucault se propõe a fazer uma arqueologia deste silêncio que se estabelece no final do século XVIII. Para tanto, no seu entender, “É necessário (...) renunciar ao conforto das verdades confirmadas, e nunca nos deixarmos guiar pelo que podemos saber sobre a loucura. Nenhum dos conceitos da psicopatol ogia deverá, mesmo e principalmente no jogo implícito das retrospecções, exercer qualquer papel organizador. É constitutivo o gesto que separa a loucura, e não a ciência que se estabelece, uma vez feita esta separação, na calma retornada. (...) Será portanto necessário falar destes gestos repisados na história, deixando em suspenso tudo o que pode fazer figura de conclusão, de repouso na verdade; falar deste gesto de corte, desta distância tomada, deste vazio instaurado entre a razão e o que não é ela, sem nunca seapoiar na plenitude do queela pretende ser" (Foucault, 1961:III).

O estabelecimento desta divisão, deste silêncio, não é, no seu entender, casual. Ele é parte de uma estratégia da recusa implementada pela razão científica, na qual a psiquiatria, a psicologia e a psicopatologia teriam desempenhado papel decisivo.

No prefácio da primeira edição, Foucault afirma que o objetivo de seu livro é analisar os mecanismos que promoveram esta estrutura da recusa. Ele se propõe a fazer uma história desta linguagem, uma arqueologia deste silêncio, do momento em que a loucura foi encarcerada pela razão.

No seu entender, para realizar tal empreendimento o pesquisador deve assumir uma nova postura metodológica. É necessário que o pesquisador, por um lado, procure apreender a loucura em sua vivacidade, antes de qualquer captura pelo saber. Ele tem, ainda, que ter os ouvidos apurados para escutar a pureza primitiva da loucura, curvando-se para esse resmungo do mundo, tentando perceber as imagens que nunca foram poesia.

Em síntese, a perspectiva metodológica de Foucault objetiva:

"Fazer um estudo estrutural do conjunto histórico - noções, instituições, medidas jurídicas e policiais, conceitos científicos - que mantém cativa uma loucura cujo estado selvagem não pode nunca ser recuperado em si mesmo; mas à falta desta inacessível pureza primitiva, o estudo estrutural deve remontar até a decisão que une e separa, ao mesmo tempo, razão eloucura; deve tender a descobrir a troca perpétua, a obscura raiz comum, o afrontamento originário que dá sentido à unidade quanto à oposição do sentido eda insensatez" (Foucault, 1961:VI).

Este empreendimento seria possível? Seria possível ouvir a loucura antes de ela ter sido capturada pelo saber? Os registros oficiais anteriores ao século XVIII não teriam sido feitos pela mesma razão que buscava silenciar a loucura?

Foucault, ele mesmo, admite a impossibilidade de sua perspectiva metodológica, afirmando:

“Mas essa é sem dúvida uma tarefa 'duplamente impossível' (destaque nosso): já que ela nosforçaria a reconstituir a poeira destas dores concretas, destas palavras insensatas que nada amarra ao tempo; ejá, princi palmente, que estas dores e palavras que só existem esão dadasa das mesmas eaos outros no gesto da divisão que já as denuncia edomina" (Foucault, 1961:VI).

\section{A opinião de Derrida}

Derrida inicia suas críticas de forma amena, respeitando o peso da obra e a importância que Foucault tinha para ele. Ele considera o “Iivro admi rável sob tantos pontos de vista, livro poderoso em seu fôlego e em seu estilo" (Derrida, 1967:51). Em tom ainda cordial, Derrida, ex-aluno de Foucault, teme, na abertura de seu artigo, que este diálogo com o mestre seja entendido como uma contestação.

Ele não encerra sua conferência, entretanto, com a mesma retórica. Segundo Derrida:

"Ao escrever uma história da loucura, Foucault quis - e nisto residetodo o valor mas também a 'impossibilidade própria de seu livro' (destaque nosso) - escrever uma história da loucura 'mesma'. Ela 'mesma'. Da própria loucura. Quer dizer, dando-Ihea palavra. Foucault quis quea loucura fosse o sujei to de seu livro; o sujei to em todos os sentidos da palavra: o tema de seu livro e o sujeito falante, o autor de seu Ii- 
vro, a loucura falando de si mesma" (Derrida, 1967:55-56).

Para Derrida, o que há de mais audacioso, mais sedutor e mais louco na perspectiva metodológica de Foucault é a tentativa de escapar à ingenuidade objetivista presente na linguagem policial e policiada da razão clássica.

Derrida mostra, ao longo de sua conferência, a impossibilidade desta 'tentativa', apresentando alguns argumentos.

Por um lado, Derrida critica a proposta de Foucault de fazer a arqueologia do si lêncio. Para ele, uma arqueologia, mesmo que fosse do silêncio, teria que ser obrigatoriamente dotada de uma lógica, de uma racionalidade. A linguagem utilizada nesta arqueologia teria, para Derrida, uma razão que Ihe daria sentido e significado.

Além disso, Derrida admite que, se quiséssemos ser os porta-vozes dos loucos, se quiséssemos escutar seu silêncio, como se dispôs Foucault, teríamos que utilizar, invariavelmente, a linguagem da ordem. Assim, o empreendimento de Foucault ficaria mais uma vez inviabilizado. No seu entender, não há como analisar algo sem se inserir em uma ordem explicativa qualquer. O silêncio, por exemplo, só pode ser compreendido numa linguagem.

No entender de Derrida, o fato de Foucault admitir a impossibilidade de seu investimento demonstra que ele tem uma consciência aguda da dificuldade deste projeto. A pretensão de construir uma arqueologia do silêncio foi considerada, por Derrida, "purista, intransi gente, não-violenta e não-dialética" (Derrida, 1967: 59). O tom amigável do início da conferência torna-se, aos poucos, árido e ácido.

Derrida identifica, ainda, uma contradição fundadora no prefácio da obra de Foucault. Se o próprio autor considera que a realização deste empreendimento é impossível dentro dos marcos metodológicos propostos, como admitir que Foucault tenha escrito um livro sobre o tema? Derrida aprofunda suas críticas perguntando: Se o próprio Foucault considerou duplamente impossível se curvar para esse resmungo do mundo e reconstituir a poeira destas dores e palavras concretas, como aceitar que ele tenha estabelecido tal perspectiva metodológica para a reconstituição de uma história da loucura?

\section{Considerações finais}

No apêndice da segunda edição - Mon corps, ce papier, ce feu -, Foucault disseca um a um os argumentos apresentados por Derrida acerca da polêmica sobre a interpretação dada às $\mathrm{Me}$ - ditações, de Descartes. Sobre as críticas que recebeu em relação à periodização e à proposta metodológica da História da Loucura não há uma só palavra. A constatação do silêncio é, para nós, no mínimo, inquietante.

Derrida, ex-aluno de Foucault, dirigiu-Ihe críticas ásperas envoltas por uma cordialidade formal. Foucault não as respondeu, pelo menos na réplica, publicada no apêndice da segunda edição da mesma obra. Esta atitude surpreendente incita nossa imaginação. Para nós é difícil conceber um gesto de autocensura vindo de quem veio.

O silêncio diante da polêmica acadêmica é sinal de concordância? O fato de ter retirado o prefácio da primeira edição quando a obra foi reimpressa indica que sim. A preservação do texto na íntegra, no entanto, sugere o contrário.

Foucault calou-se, mas não consentiu. Calou-se quando não respondeu às críticas de Derrida e impediu que o prefácio integrasse a segunda edição. Não consentiu, pois manteve a História da Loucura intacta, inalterada, transformada, depois, numa referência internacional sobre o tema. Além disso, ele já havia admitido a impossibilidade de sua obra, defendendo a adoção de uma rel atividade sem recurso em sua proposta metodológica.

Um estudo que analisasse a momento profissional, pessoal epsicológico que Foucault vivia no início da década de 60 e o comparasse com aquele da década de 70 talvez apresente pistas interessantes para desvendar a questão que motivou a realização deste artigo. Um indício da condição psicológica em que Foucault se encontrava nos anos 60 pode ser observada nas últimas linhas do prefácio da primeira edição. Foucault agradece aos amigos suecos e poloneses, que conheceu em Hamburgo, e pede que Ihe perdoem "por têlos feito sofrer, eles e sua felicidade, tão próximos de um trabal ho onde só se tratava de sofrimentos longínquos, e dos arquivos um pouco empoeirados da dor" (Foucault, 1961:VIII).

Outra possibilidade de entendimento desta atitude de Foucault talvez esteja associada a uma análise das escolas de pensamento que ele e Derrida integraram ao longo dos anos $60 / 70$. Por certo a polêmica por eles travada não se circunscreve, exclusivamente, a este prefácio ou a esta obra. Caberia, portanto, recuperar al guns elementos integrantes da relação intelectual que foi estabelecida, ao longo do tempo, entre Foucault e Derrida. Neste mesmo percurso, deve-se levar em consideração o campo intelectual francês no pós-guerra, em um sentido mais amplo, sobretudo o entrechoque do estrutural ismo racionalista nietzschia- 
no com as correntes neo-românticas heideggerianas, que inspiraram, em certa medida, o pensamento destes dois intelectuais.

As chaves do entendimento deste episódio talvez estejam, ainda, associadas à historicidade inerente ao momento da produção científica da História da Loucura e também presentes numa análise histórica desta obra no conjunto da carreira de Foucault.

Estimulado pelo texto, à guisa de especulação, se há razões que a própria razão desconhece, poderíamos procurar compreender este

\section{Agradecimentos}

Agradeço às sugestões feitas pelo Prof. Dr. André R. Rios (Instituto de Medicinal Social, Universidade do Estado do Rio de Janeiro) durante a elaboração deste texto e ao excelente trabalho de tradução dos originais feito por Laís Eleonora Vilanova. gesto de Foucault dentro de um contexto de susceptibilidades, conflitos de vaidades e de encarniçadas lutas por prestígio e poder que dominam a arena acadêmica. Será que os mestres, da envergadura dos supracitados, estariam infensos a esta contingências? Tenho sinceras dúvidas.

As possíveis razões pelas quais Foucault tomou tal iniciativa permanecem obscuras. Neste trabalho pretendíamos tão-somente propor uma agenda de pesquisa sobre uma temática tão complexa quanto instigante.

\section{Referências}

FOUCAULT, M., 1961. Folie et Déraison. Histoire dela Folieà l'âge Classique. Paris: Plon.

FOUCAULT, M., 1972. Folie et Déraison. Histoire de la Folieà l'âge Classique. Paris: Gallimard.

DERRIDA, J., 1967. Cogito et histoire. In: L'Ecriture et Ia Difference (J. Derrida, ed.), pp. 51-97, Paris: Seuil. 